\title{
SPECTACULAR FORMS OF ANCIENT ROME EVENTS IN THE CULTURAL STUDIES DIMENSION
}

\section{Goncharova Olena}

\section{INTRODUCTION}

The scientific and popular science literature is devoted to spectacular ancient culture and its individual forms. The authors of some of these cultural studies, philosophical, historical, literary and pedagogical studies have already become classics and indisputable authorities in this field: S. Averintsev, J. Burckhardt, V. Dmytrenko, F. Cowell, O. Losiev, Th. Mommsen, A. Obertynska, S. Utchenko, G. Hyofling, I. Schiffman, R.C. Beacham, L. Gorgerat, A. McCullough, D. McLean, T. Wiedemann, G. Woolf and others. However, while focusing on the ancient leisure as, above all, free time, the quantity and quality of which signifies a measure of social wealth of the Greeks, transformational changes in Roman leisure culture, defining the ancient leisure as a scholastic (gr. $-\sigma \chi 0 \lambda \alpha$ ), intellectual and spectacular otium, often the insufficient attention is paid to the moment that performances of athletes, poets, rhapsodists, actors and gladiators were public, so they were the forms of existing spectacular events - prototypes of modern cultural and leisure, and recently - due to television - entertainment shows in leisure industry.

Increasingly, in various fields of humanitarian knowledge, humanity turns to the understanding of dynamism and dialectic of historical movement and realization of cultural values, which are considered not only as objective characteristics of culture making it possible to understand the concept of value as the integrity of cultural traditions, richness of their manifestation at different levels of social activity, but also as a set of mechanisms, norms and rules of social interaction produced by civilization in the context of spectacular culture. The axiological approach to the essence of culture of free time 
becomes fundamental in the field of events, as it paves the way for expanding the functions of leisure activities and enriching its forms and content. The reference point for axiological approach in the social and cultural sphere is the values of spectacular forms of Antiquity events, the study of which is productive and certainly significant for modern spectacular culture. Paintings, sculptures, museum exhibitions, novels, movies, television series, comics, plays and historical reconstructions at Roman festivals are devoted to the theme of spectacular events of the ancient Rome that indicates the longstanding interest of the public, and not just the scientific one.

On the other hand, less attention was usually paid to games, entertainment, performances and events of the ancient world in the studies of G. Avanesova, O. Henkina, O. Kliusko, H. Novikova, I. Petrova, B. Chumachenko devoted to the leisure culture. Therefore, the author of this monograph section aims to define the genesis and evolution of the forms of events in the ancient Rome, to investigate its functions, to establish how the Antiquity events arose in the context of spectacular culture of Rome.

Methodological basis of the monograph section consists of the methods of critical analysis of cultural, historical and literary sources, specific and historical analysis and interdisciplinary synthesis, induction and deduction. The problematic and chronological, system and structural methods, as well as the method of social and phenomenological analysis were applied from specific and scientific methods. New approaches to the study of cultural and historical process increase the opportunities in investigation of spectacular events as a social and cultural phenomenon, identification of the place of spectacular culture of Antiquity in the system of cultural knowledge, in the cultural tradition of their social universe ${ }^{1}$.

1 Kliusko E.M. (2007) Dosug v kontekste sovremennykh vzglyadov na istoriografiyu [Leisure in the context of modern views on historiography]. Social and cultural activities: experience of historical research; collection of articles. Sc. ed. E.M. Kliusko, N.N. Yaroshenko. M.: MGUKI, pp. 33-34 (in Russian). 
The genesis and evolution of spectacular forms of eventsof Antiquity, functional features of cultural and leisure practices, specific features ofspectacular culture of Antiquity can be investigated by analyzing the works of Mark Tullius Cicero, historical works of Gaius Suetonius Tranquillus, Josephus Flavius, annals of Publius Cornelius Tacitus, biographies of Plutarch, ethic works of Lucius Annaeus Seneca, letters of Gaius Pliny the Younger, works of Lucius Apuleius, Macrobius Theodosius, poetry pages of Publius Ovidius Naso, epigrams of Marcus Valerius Martialis, works of Saint John Chrysostom, hagiographic works of Dimitry of Rostov and others.

The forms of spectacular Antiquity events are numerous and varied: sports competitions, theatre performances and choirs, religious holidays - passing of donators, games in honor of gods, poetry competitions, performances of rhapsodists, circuses and actors, performances in theaters, mass performances and entertainment in amphitheaters, circuses, gladiatorial shows, naumachias, chariot racing. This also includes speakers at the Roman Forum, in the Senate.

The axiological principles of leisure of the ancient society were based on political and personal liberty of the individual, education of model paradigmatic citizen, on the priority of polytheistic religion and state ideology, active development of visual, literary and dramatic creativity $^{2}$. In general, there are no differentiation in the culture in the ancient world to which we are used - folk and scientific culture, mass and elite, formal and informal, local (peripheral, provincial) and capital (cultural metropolitan), no bohemianism, underground, youth culture, etc ${ }^{3}$.

${ }^{2}$ Chumachenko B.M. (2003) Vstup do kuljturologhiji antychnosti [Introduction to the cultural studies of antiquity]. K.: KM Akademiia Publishing House, pp. 11-12 (in Ukrainian).

${ }^{3}$ Chumachenko B.M. (2003) Vstup do kuljturologhiji antychnosti [Introduction to the cultural studies of antiquity]. K.: KM Akademiia Publishing House, pp. 24 (in Ukrainian). 
The leisure and events differentiate only in the forms of participation of free citizens - leisure activities that take place at home and those that take place in public places on city street. Domestic and non-domestic activities are related to traditional games, sports competitions requiring either direct human involvement or monitoring their progress.

Free time, quantity and quality of leisure become a measure of a person's social wealth in Antiquity. Power, politics, war as arete, leisure, sports and physical culture are valued, but the physical labor is neglected. Amphitheaters, theaters, stadiums, circuses, hippodromes, courts are the most visited places by the Romans. The Romans built what they needed for play, leisure, entertainment and events as a necessary condition of the Roman way of life. The ancient Romans loved agons and spectacles, but were more likely as passive spectators than participants, despising gladiators as criminals and actors as comedians ${ }^{4}$.

Among the forms of mass spectacles of the ancient Rome, the Spanish researcher R. Beacham identifies comedies, tragedies, pantomimes, triumph ceremonies, funerals, gladiatorial shows, shows with wild animals, processions in the circus, which were influenced significantly by the Roman, Etruscan and African traditions. The ideas of celebrations were influenced by political, social, religious characteristics and state control ${ }^{5}$.

\section{Games and holidays: genesis of cultural practices of the Ancient Rome}

The origin of Roman games, festivals and spectacle is inseparable from the history of local beliefs, cults and religious ceremonies. The ancient Italians did not know the anthropomorphism, and it was only

${ }^{4}$ Chumachenko B.M. (2003) Vstup do kuljturologhiji antychnosti [Introduction to the cultural studies of antiquity]. K.: KM Akademiia Publishing House, pp. 57 (in Ukrainian).

${ }^{5}$ Beacham R.C. (2001) Spectacle Entertainments in early imperial Rome. Revista de Estudios Latinos (RELat), V. 1, p. 280. 
under the influence of the Etruscans (and later the Greeks) that the Romans began to represent their gods and goddesses in human form. In Italy, the deities of the farmers Ceres and Mars were eagerly honored. The latter only over the time became the all-powerful patron of the city of Rome, being considered the father of Romulus. Among the most common Roman games are Agonalia (January, May, December), Megalese Games - festival of the Great Mother of Gods (March), Fish Games (June), Roman Games - festival of Jupiter, Juno and Minerva (September, November) and others.

The winners of games and competitions in the Roman Empire were honored, about which Pliny the Younger wrote in a letter to Emperor Trajan "The winning athletes in the Triumphal Games, Sir, think that they ought to receive the prizes which you have awarded on the day they are crowned for victory. They argue that the actual date of their triumphal entry into their native towns is irrelevant; the date which matters is that of the victory which entitled them to the triumph"6.

A special place in the life of the Romans is occupied by Saturnalia festival. As the Roman philosopher and philologist Macrobius Theodosius notes in his work "Saturnalia", "it is more correct to say "Saturnalibus ... Satumalium" than "Saturnalia", During favorite festival that lasted from December 17 to December 23, the Romans sent each other gifts, lit candles, the slaves were treated at the same table with the masters. Macrobius recalls the times when "... the Cyrenaicans are crowned with fresh figs and send cakes to each other... then they had not yet divided people by their condition as slaves and free ... during Saturnalia the slaves are granted

${ }^{6}$ Sergeenko M.E., Dovatur A.I. (editors) (1982) Pisma Pliniya Mladshego: Knigi $I-X$ [Pliny the Younger: Letters: Books I-X]. 2nd edition. Book X, 118 (in Russian).

Macrobius Theodosius (2013) Saturnalii [Saturnalia]; translation by V.T. Zvirevich. M.: Krug, Vol. 4. Book 1, II, 5. (Humanities in research and translation) (in Russian). 
complete freedom ${ }^{8}$. The games that were held on the crossroads at Compitalia festival were restored, according to Macrobius, during the reign of Tarquinius the Proud for lares. Compitalia (compitorum crossroad) was accompanied by human sacrifices (children's - O.G.) that were cancelled only by consul Junius Brutus after Tarquinius was overthrown and were replaced with the use of garlic and poppy heads ${ }^{9}$.

The ancient Greek historian Plutarch in "Comparative Biographies of Caesar" examines in detail the features of Lupercalia festival, which in the ancient times was the festival of herders. The author is amazed how many young people from noble families, and even persons holding high official positions "many of the noble youths and of the magistrates run up and down through the city naked, for sport and laughter striking those they meet with shaggy thongs. And many women of rank also purposely get in their way, and like children at school present their hands to be struck, believing that the pregnant will thus be helped in delivery, and the barren to pregnancy" $" 10$.

In the culture of antiquity the traditions were formed that could bring together a large number of people during common festivals. The common festivals rooted in the ancient rites were associated both with religion and folk calendar and labor customs. These celebrations included spectacular entertainment shows, which became the first mass events in the history. The festivals were divided into national and lower-ranking, official and family, rural and urban, constant or occasional, festivals of individual deities and professions.

8 Macrobius Theodosius (2013) Saturnalii [Saturnalia]; translation by V.T. Zvirevich. M.: Krug, Vol. 4. Book 1, VII, 25-26. (Humanities in research and translation) (in Russian).

9 Macrobius Theodosius (2013) Saturnalii [Saturnalia]; translation by V.T. Zvirevich. M.: Krug, Vol. 4. Book 1, VII, 34-35. (Humanities in research and translation) (in Russian).

${ }_{10}$ Plutarch (1994) Sravnitelnye zhizneopisaniya $v$ dvukh tomakh. Tsezar. [Comparative life descriptions in two volumes. Caesar]. Editor S.S. Averintseva. M.: Nauka, Ed. 2. Vol. II, p. 61 (in Russian). 
The priests played a special role in the celebration. The duties of the priests, as Cicero wrote in a speech "On the Responses of the Haruspices", included maintaining chariots (tensae), opening songs, games, casting of sacrifice, banquet regarding the games... All prescriptions during games were observed with complete reverence and respect for all regulations" 11 .

The spectacular nature of the ancient Roman culture of events was so pronounced that the games, for example, later became an important component of domestic politics. The German historian Th. Mommsen writes that a certain amount of 200000 aces (14500 thalers) was allocated from the state treasury for the games and that amount was not increased until the Punic Wars. These funds were managed by aediles, which had to cover all sorts of accidental expenditures themselves ${ }^{12}$. The newly elected Roman aediles were obliged, along with other issues of city government, to solve the issue of city population entertainment (curul aedile as a patrician magistrate was created as early as $367 \mathrm{BC}$ ). Taking this into account, the candidates for this position promised certain spectacular exclusives in their election "programs". The entertaining and spectacular moment of politics was so powerful that a law (Tullius's law) passed in $63 \mathrm{BC}$ by Marcus Tullius Cicero was adopted, which, among other things, prohibited candidates for the highest positions in the Roman Republic to organize spectacles for people to buy the votes.

On the eve of taking the position of aedile, Cicero himself proclaims that the games he will offer to the Roman people after his election will be his speeches with reports on public affairs and dishonest people. "These will be," Cicero says in his first speech

${ }^{11}$ Cicero Marcus Tullius (1962) Rech ob otvetakh garuspikov. Rechi $v$ dvukh tomakh [On the Responses of the Haruspices. Speeches in two volumes]. Moscow: Publishing House of the Academy of Sciences of the USSR, Vol. 2, p. 189 (in Russian).

${ }^{12}$ Mommsen Th. (1997) Iskusstvo i nauka. Istoriya Rima [Art and Science. History of Rome]. Editor-in-chief A.B. Yegorov, editor N.A. Nikitin. St. Petersburg: "Nauka", "Yuventa", p. 365 (in Russian). 
"Against Verres", those games that I, as aedile, will organize for the Roman people ..."

It is known that the Romans prized the city authorities not only for bread, but also for mass spectacles. Therefore, each new aedile tried to impress the Romans with something unusual and thus please them. For example, during the games in 103 BC, Lucius Licinius Crassus while holding the position of cural aedile with another aedile Quintus Mucius Scaevola for the first time showed the lions to the Romans and during the games in 99 BC, another cural aedile Gaius Claudius Pulcher entertained the residents of the Eternal City with elephants.

In August $46 \mathrm{BC}$, Caesar celebrated a magnificent triumph in honor of the victory over Gaul, Egypt, Pontus and Africa. The celebration lasted four days, one more day was specially reserved for rest. S. Utchenko draws attention to the fact that immediately after the triumph he generously paid to his army, in particular the ordinary warrior received 5000 Attic drachmas, centurion - twice as much, stands and heads of horse cavalry - four as much. Each resident of Rome received 400 sestertii, 10 modii of grain (1 modius - 8704 liters. - O.G.) and 10 pounds of oil. The great feast of 22,000 tables was arranged for people, as well as spectacles and games involving infantrymen, cavalry and even war elephants $^{14}$.

The more customized leisure becomes characteristic of representatives of the upper classes, elite, self-employed people who were able to use slaves. According to G. Woolf, the social link between education, social mobility and acculturation suggests that this

${ }^{13}$ Cicero Marcus Tullius (1962) Rech protiv Gaya Verresa (Pervaya sessiya). Rechi v dvukh tomakh [Speeches against Verres (First session). Speeches in two volumes]. Moscow: Publishing House of the Academy of Sciences of the USSR, Vol. 1, p. 53 (in Russian).

${ }_{14}$ Utchenko S.L. (1972) Tsitseron i ego vremya [Cicero and his time]. M.: Mysl, p. 270 (in Russian). 
representation played a role in creation of imperial elite by joining local elite groups to the empire ${ }^{15}$.

In his letters to the Emperor Trajan, Pliny the Younger repeatedly writes about leisure, different types and forms of rural and urban recreation, recreation at villa, recreation and entertainment at sea, feast, grape harvesting, wine, spectacles, circus games, chariot racing, organization of religious festivals in the context of temple restructuring in the own estate, construction of theater and thermae, awarding athletes for winning the elastic competitions ${ }^{16}$. It is noteworthy that at any moment Pliny the Younger is ready to interrupt his literary work in the city for the rural leisure.

In his epigrams "To Julius Martial", the Roman poet Marcus Valerius Martial describes:

...if it rested with us to dispose of our leisure time,

and to spend in each other's company a life of true ease,

we should know no halls or mansions of lordly patrons,

nor vexatious lawsuits and troubles of courts,

nor proud family busts; but carriage airings,

conversation, reading, the Campus Maximus,

the shady porticoes, the Virgin water, the warm baths;

such places would be our constant resorts ${ }^{17}$.

\section{Events in theaters VS spectacle in circuses, amphitheater: theoretical reflection}

The theaters appeared and dramaturgy developed in the ancient Rome. As a rule, dramatic art remained closely related to national

${ }^{15}$ Woolf, Gregory Duncan (2001) Inventing empire in ancient Rome. Empires Perspectives from archaeology and history. Editors S.E. Alcock; K.D. Mor; T.N. D'Altroy, K.D. Morrison, C.M. Sinopoli. Cambridge University Press, p. 320.

16 Sergeenko M.E., Dovatur A.I. (editors) (1982) Pisma Pliniya Mladshego: Knigi I-X [Pliny the Younger: Letters: Books I-X]. 2nd edition. Book IX, 32. Books I, 3; I, 9; IX, 7; IX, 36; IX, 40. Book. IX, 33. Books I, 15; IX, 17. Book IX, 20. Books IX, 6; IX, 23. Book IX, 39. Book X, 39. Book X, 118 (in Russian).

Martialis M.V. (1968) Epighramy. Antychna literatura; khrestomatija [Epigrams. Ancient literature; chrestomathy]. Compiled by O.I. Biletskyi. K .: Rad. shkola, p. 550 (in Ukrainian). 
consciousness, mythology, but at the same time it already contained original stories, masterfully reflecting thoughts and feelings common to time and individual experience. The organized entertainment in the first three centuries of the republic developed quite slowly.

As F. Cowell notes in his book "Ancient Rome. Life, religion, culture", the theatrical performances were not an extraordinary event among the Greek and Etruscan neighbors of Rome, and began to be staged in temporary theaters after Roman soldiers spent 20 years in Sicily during the first war with the Phoenicians. The island was then divided between the Carthaginians and the Greeks. After several defeats, the Greeks united with the Romans, and the Roman legionnaires for the first time faced a new art form in the tragedies of Euripides and comedies of Menander. The theatrical performances, pantomimes (from Greek. panta - everything) were depicted by the language of dance, gestures and without words. The actors were then called "Apollo's table companions", among them were the Quindecimviri (15 men for sacred rites). In the first year of peaceful life (240 BC), a play in Latin was staged in Rome, which ignited the public's taste for more. Over the next 150 years, almost all comedies and tragedies of Roman literature were written ${ }^{18}$.

In his "Moral Letters to Lucilius" Lucius Annaeus Seneca writes about the popularity of recreation in theater more than of philosophical conversations, describing those "praeter ipsum theatrum Neapolitanorum, ut scis, transeundum est Metronactis petenti domum. Illud quidem fartum est, et ingenti studio quis sit pythaules bonus iudicatur; habet tubic quoque Graecus et praeco concursum: at in illo loco in quo source bonus quaeritur, and quo source bonus discitur, paucissimi sedent, et hi plerisque videntur nihil boni negotii habere

${ }^{18}$ Cowell F. (2006) Drevniy Rim. Byt, religiya, kultura [Ancient Rome. Life, religion, culture] (electronic source). M.: Centrpoligraf. Retrieved from: http://historylib.org/historybooks/Drevniy-Rim--Byt--religiya--kultura/ (accessed on September 15, 2019) (in Russian). 
quod agant; inepti et inertes vocantur ${ }^{19}$... On my way to the house of Metronax I am compelled to go, as you know, right past the Neapolitan Theatre. The building is jammed; men are deciding, with tremendous zeal, who is entitled to be called a good flute-player (flutist who accompanied solo parts of actors in antique theater O.G.); even the Greek piper and the herald draw their crowds. But in the other place, where the question discussed is: "What is a good man?" and the lesson which we learn is "How to be a good man," very few are in attendance, and the majority think that even these few are engaged in no good business; they have the name of being emptyheaded idler ${ }^{20}$.

Before the decline of the republic, the theater as a form of art was almost "dead". The comedies of Plautus, Terence, Attius, tragedies of Ennius, Naevius, Pakuvius, and later tragedies of Seneca cannot be called a succession. As most of them are written in Greek originals, they were not of a high quality or remain unvalued. They simply could not compete with competitive forms of entertainment that were much more attractive for the Roman crowd. The mimes, pantomimes and knockabout acts still gathered crowds in theaters, but during the empire mentioning the games (ludi) that included theatrical entertainment for more people meant exciting chariot racing in the Great Circus and, above all, bloody gladiatorial shows in the amphitheater ${ }^{21}$.

${ }^{19}$ Seneca Lucius Annaeus (1977) Nravstvennye pisma $k$ Lutsiliyu [Moral letters to Lucilius]. Translation, notes by S.A. Osherov, ed.-in-chief M.L. Gasparov. M.: Nauka, LXXVI, 4. (Literaturnye pamyatniki series [Literary Monuments series]). Retrieved from: http://yakov.works/acts/01/2/seneca_001.htm (accessed on February 19, 2015) (in Russian).

${ }^{20}$ Seneca Lucius Annaeus (2011) Moraljni lysty do Lucylija [Moral letters to Lucilius]. Translated from Latin by A. Sodomora. K.: Apriori, pp. 132-133 (in Ukrainian).

${ }^{21}$ Cowell F. (2006) Drevniy Rim. Byt, religiya, kultura [Ancient Rome. Life, religion, culture] (electronic source). M.: Centrpoligraf. Retrieved from: http://historylib.org/historybooks/Drevniy-Rim--Byt--religiya--kultura/ (accessed on September 15, 2019) (in Russian). 
The development of secular mass and spectacular musical and circus art, the independent forms of which appeared in different regions of the ancient world is especially worth mentioning. The Greeks and Romans were the first to hold mass spectacles - theatrical, sports and circus. The programs of celebrations have changed over the centuries: the constant elements such as sacrifices, prayers and solemn marches were supplemented with activities that are just spectacular and entertaining. These could be gladiatorial shows or fights with wild beasts in the amphitheater, chariot racing in the circus, theatrical performances. The spectacles in Rome were a form of cult celebrations, form of honoring the gods, a kind of mystery, mass entertainment, and had a competitive nature. The spectacular events of the ancient Rome were magnificent, even under criteria of our time.

In the cultural and leisure sphere in the ancient Rome, the customized forms of leisure were increasingly opposed to mass, domestic to socially organized, intellectual activities were shifted towards physical, spiritual and developing forms of leisure were partly replaced by spectacles encompassing thousands of people at the same time.

The Emperor Claudius should be noted among the game organizers, as he often showed large and numerous spectacles, and not only ordinary and in ordinary places: he invented new and renewed old ones. During inauguration of the Theatre of Pompey, which he rebuilt after the fire, the emperor himself opened the games from the stand in the middle of the orchestra. As the Roman historian Gaius Suetonius Tranquillus writes in the biography of the Roman emperors "The Twelve Caesars. Divine Claudius", he often arranged circus games even in the Vatican, sometimes showing venatio after every five races. "In Circus Maximus he put the marble fences and gilded turning pillars - formerly they were made of tufa and wood - and allocated special seats for senators, who at that time sat with all other people. Here, in addition to chariot racing, he also represented the Trojan Games and African baiting with participation of a squad of Praetorian horsemen led by the stands and the prefect himself, as well 
as brought out the Thessalian horsemen with wild bulls whom they chased around the circus, picked up the exhausted ones on the back and threw them to the ground",22. During the reign of the Emperor Claudius there were 159 public festivals per year, 93 of which were devoted to games at the expense of government expenditures, including celebrations in honor of national heroes and victories in battles $^{23}$.

The Roman historian Publius Cornelius Tacitus in his "Annals" among the active hobbies of another Emperor Nero (stepson of Claudius - O.G.) notes such an activity as "riding horses in the tiltyard"24. Even Tacitus himself was a priest-quintecimvir, organizer during secular games hosted by the Emperor Claudius. "During the games that took place at the circus in the presence of Claudius, teenagers from noble families, among them Britannicus, son of the emperor, and Lucius Domitius (Nero - O.G.) ... gave a Trojan performance on horseback" $" 25$.

The chariot racing was particularly popular in Rome and, despite being very dangerous, they did not have the deliberate cruelty of fighting as in fighting of man with wild beasts. They were held in one of the five or six circuses of imperial Rome, the largest and oldest of which was large Circus Maximus (Circo Massimo). Its length was 600 yards and width -200 yards. After expanding during the empire,

${ }^{22}$ Suetonius G.T. (1990) Zhizn dvenadtsati tsezarey [The Twelve Caesars]. Translation from Latin, foreword and afterword of M. Gasparov. M.: Khudozhestvennaya literatura, V. 21. Retrieved from: http://ancientrome.ru/ antlitr/t.htm?a=1354644432 (accessed on January 17, 2015) (in Russian).

${ }^{23}$ Woolf, Gregory Duncan (2001) Inventing empire in ancient Rome. Empires Perspectives from archaeology and history. Editors S.E. Alcock; K.D. Mor; T.N. D'Altroy, K.D. Morrison, C.M. Sinopoli. Cambridge University Press, p. 320.

24 Tacitus Publius Cornelius (2001) Annaly. Malye proizvedeniya. Istoriya. [Annals. Small works. History]. Translation from Latin. M.: Publishing House AST LLC; Ladomir, XIII, 3. (Klassicheskaya mysl series [Classical thought series]) (in Russian).

${ }^{25}$ Tacitus Publius Cornelius (2001) Annaly. Malye proizvedeniya. Istoriya. [Annals. Small works. History]. Translation from Latin. M.: Publishing House AST LLC; Ladomir, XI, 10. (Klassicheskaya mysl series [Classical thought series]) (in Russian). 
it was able to accommodate about 250,000 viewers. Most of them were sitting on wooden seats behind the front stone rows that were intended for the Vestal, senators and horsemen. Four teams, owned by contractors, competed for favor of the crowd - red, green, white and blue, named so for the color of clothing of the chariot drivers standing on fragile two-wheeled chariots behind two or four horses, wrapping the reins around their bodies. They needed to free themselves quickly by cutting the reins if the chariot turned over. The emotions run high on the side of one of these team colors and could split families and destroy friendships. Remembering the victories of one of the most famous chariot driver Diocles (about 150 AD), G. Hyofling in "Ancient Rome. Life, religion, culture" describes his tombstone. It contains the story of 3000 victories in racing on two-horse chariots, and of 1462 victories in chariots harnessed of more than two horses ${ }^{26}$.

However, not all residents of Rome favored such races. Pliny the Younger in his letter to Calvisius mentions the circus games, noting that he does not favor such empty vulgar spectacles and prefers literary work. The Roman horsemen familiar with literary works of Cornelius Tacitus and Pliny the Younger himself (except that the audience sometimes confounded these authors, asking which of them was "Italian" and which was "provincial") were among the visitors to circus games ${ }^{27}$.

The author is amazedby the mass interest in chariot racing and the fact that "thousands of men should be eager, like a pack of children, to see horses running time after time, and the charioteers bending over their cars. There might be some reason for their enthusiasm if it was the speed of the horses or the skill of the drivers

26 Hyofling G. (2010) Rimlyane, raby, gladiatory: Spartak u vorot Rima [Romans. Slaves. Gladiators. Spartacus at the gates of Rome]. M.: Center polygraph. Retrieved from: http://historylib.org/historybooks/KHelmut-KHefling_Rimlyane-raby--gladiatory-Spartak-u-vorot-Rima/2 (accessed on February 12, 2015) (in Russian).

7 Sergeenko M.E., Dovatur A.I. (editors) (1982) Pisma Pliniya Mladshego: Knigi I-X [Pliny the Younger: Letters: Books I-X]. 2nd edition. Book IX, 23 (in Russian). 
that was the attraction, but it is the racing-colors which they favor, and the racing-colors that fire their love. If, in the middle of the course and during the race itself, the colors were to be changed, their enthusiasm and partisanship would change with them, and they would suddenly desert the drivers and the horses, whom they recognize afar and whose names they shout aloud. Such is the influence and authority vested in one cheap tunic, I don't say with the common crowd, - for that is even cheaper than the tunic, - but with certain men of position; and when I consider that they can sit for so long without growing tired, looking on at such a fruitless, cheerless, and tedious sport" ${ }^{\prime 28}$.

Pliny the Younger expressed his attitude to the races in writing in letters. However, later the verbalized position of other citizens could be public. In particular, Gordius, centurion of Caesarea of Cappadocia, during the reign of Roman emperor Lycinius (307-324) came to the circus to express his civil and religious Christian beliefs during the festival of Mars. Then, as the historian of the XVII century Dimitry of Rostov writes in the compilation "Cheti-Minei" (Daniil Tuptalo, monk of the Kyiv Pechersk Lavra, Metropolitan of Rostov), "all the people came to the circus to watch horse racing, and all were sitting on high seats ... the audience watching the fast running of horses and skills of riders.On this day the slaves were released from work and gathered there, children hurried here from school ... When the herald signaled silence, the pipes, swirels and musical instruments fell silent". Due to religious Christian beliefs Gordius was publicly punished, and the mayor ordered "to stretch him on wheels and tear his body apart; hang on a tree; ... give it to the beasts, cut his head off and throw it into the abyss" ${ }^{29}$. The public executions, in this case of

28 Sergeenko M.E., Dovatur A.I. (editors) (1982) Pisma Pliniya Mladshego: Knigi I-X [Pliny the Younger: Letters: Books I-X]. 2nd edition. Book IX, 6 (in Russian).

29 Dimitry of Rostov (2006) Zhitiya svyatykh, izlozhennykh po rukovodstvu Chetikh-Miney v 12 tomakh [The Lives of Saints based on Cheti-Minei in 12 volumes]. K.: Publishing House of Kyiv Pechersk Lavra, Vol. 5, pp. 143-144 (in Russian). 
Christians, have become a kind of mass "spectacles" attracting a lot of people among the audience.

Catherine, resident of Alexandria, has met the same fate of public execution during the reign of Roman Emperor Maximinus (305313 years). An eighteen-year-old girl of royal lineage with good education and knowledge of several languages "perfectly learned the ancient poets and philosophers Homer, Virgil, Aristotle, Plato and others ... learned the works of famous doctors Asclepius, Hippocrates and Galen, also she learned the oratory and dialectical art", was publicly tortured for her religious Christian beliefs. On the advice of Hursaden, the king tortured Catherine, "four wooden wheels were mounted on one axis, and various iron spines were mounted around them: two wheels turned to the right and two to the left; in the middle of them ... the girl was tied" ${ }^{\text {"30 }}$.

The Empress Augusta, military commander Porphyry and another 200 soldiers were suffered together with Catherine ${ }^{31}$.

The King Herod before his own death carried out the mass execution of Jews at the Hippodrome. As the Roman historian of the I century BC Josephus Flavius writes in the work "Antiquities of the Jews", "the soldiers should surround the Hippodrome, and put all the inclosed persons to the sword, and then publish his death, which, (as he said) would cause his exit to be doubly triumphant; first, for the posthumous execution of his commands; and, secondly, for the quantity and number of his mourners" 32 .

However, not all rulers made mass spectacle from the execution. Thus, Pliny the Younger while being as governor in Bithynia, Roman

30 Dimitry of Rostov (2006) Zhitiya svyatykh, izlozhennykh po rukovodstvu Chetikh-Miney v 12 tomakh [The Lives of Saints based on Cheti-Minei in 12 volumes]. K.: Publishing House of Kyiv Pechersk Lavra, Vol. 3, pp. 675-676 (in Russian).

31 Dimitry of Rostov (2006) Zhitiya svyatykh, izlozhennykh po rukovodstvu Chetikh-Miney v 12 tomakh [The Lives of Saints based on Cheti-Minei in 12 volumes]. K.: Publishing House of Kyiv Pechersk Lavra, Vol. 3, pp. 677-679 (in Russian).

32 Flavius Josephus (1994) Iudeyskie drevnosti [Antiquities of the Jews]. Translation from Greek by G.G. Geakel; foreword and notes by V.A. Fedosik, G.I. Dovgialo. Minsk, Vol. 2. XVII, 6, 5 (in Russian). 
province (until probably $113 \mathrm{AD}$ ), "have never been present at any legal examination of the Christians, and I do not know, therefore, what are the usual penalties passed upon them, or the limits of those penalties, or how searching an inquiry should be made. I have hesitated a great deal in considering whether any distinctions should be drawn according to the ages of the accused; whether the name of being a Christian, even though otherwise innocent of crime, should be punished, or only the crimes that gather around it?". In letters to the Emperor Trajan Pliny the Younger wrote that with persons who have been reported as Christians he acted as follows "I ask them whether they are Christians, if they say "Yes," then I repeat the question the second time, and also a third - warning them of the penalties involved; and if they persist, I order them away to prison. For I do not doubt that - be their admitted crime what it may - their pertinacity and inflexible obstinacy surely ought to be punished. There were others who showed similar mad folly, whom I reserved to be sent to Rome, as they were Roman citizens" 33 .

The constant mass spectacles, including bloody ones, required considerable organizational work with the public and special premises.

The first amphitheater in Rome was built in the middle of the I century BC by Gaius Scribonius Curio. Then, in 46 BC, the wooden Caesar's amphitheater followed the wooden amphitheater with two rotating parts. Under the emperor Augustus, the first stone amphitheater in Rome was built on the Field of Mars by the city prefect Titus Statilius Taurus. As V. Dmytrenko writes in the monograph "Octavian Augustus. Birth of the Roman Empire", Octavian Augustus at the end of his reign "was proud that he found a

33 Sergeenko M.E., Dovatur A.I. (editors) (1982) Pisma Pliniya Mladshego: Knigi I-X [Pliny the Younger: Letters: Books I-X]. 2nd edition. Book X, 96 (in Russian). 
city of bricks and left a city of marble ${ }^{\Re 4}$. In the middle of the I century the Amphitheater of Nero was built. In Pompeii, the prominent citizens Gaius Cuspius Pansa and his son built an amphitheater, which was destroyed in $62 \mathrm{AD}$ by an earthquake, and then built a new one - shortly before the fatal eruption of Vesuvius in 79. However, the largest and most famous Roman amphitheater was built in the 70's of I century AD between the Palatine Hill and Esquiline Hill by the Emperors Vespasian and Titus: it was a huge, monumental Flavian Amphitheatre, later called the Colosseum or the Coliseum. It could accommodate more than 45000 viewers at one time (some writers even talk about 80000 or 87000 ).

The Colosseum was inaugurated by the Emperor Titus with the most generous games. It was announced that they would last a hundred days. The fights to the death were expected between more than 10000 people condemned to death and 5000 wild animals. On the second day, horse racing was to be held, and on the third - a naval battle between 3000 people on the artificial lake, which a water-filled arena turned into ${ }^{35}$. As Thomas Wiedemann notes in the book "Emperors and Gladiators", the Colosseum symbolized the emperor's own legitimacy, demonstrating that he returned the Roman people their right to decide and choose life or death. It was appropriate that the inauguration of the new birth of Roman freedom should be celebrated not only by the traditional slaughter of animals. Each time, during the battles, gladiators displayed the spectacle of death and rebirth in the presence of the Roman people. The audience

${ }^{34}$ Dmytrenko V. (2011) Oktavian Avghust. Narodzhennja Rymsjkoji imperiji [Octavian Augustus. Birth of the Roman Empire]. Lviv: Kalvariia, p. 253 (in Ukrainian).

${ }^{35}$ Cowell F. (2006) Drevniy Rim. Byt, religiya, kultura [Ancient Rome. Life, religion, culture] (electronic source). M.: Centrpoligraf. Retrieved from: http://historylib.org/historybooks/Drevniy-Rim--Byt--religiya--kultura/ (accessed on September 15, 2019) (in Russian). 
had to accept mortality, reflecting on the unprecedented strength and continuity of the universal rules of Rome ${ }^{36}$.

The amphitheaters were built also in other cities of Italy and provinces: Pompeii, Spoleto, Pozzuoli, Pula, Verona, Prenesto and many other places, in Gaul - Arelate (Arles), Nemausa (Nimes), Lutetia (Paris), Vesunna (Perisi), in Spain - in modern-day Merida to Seville, as well as on the island of Sardinia, Tunis. The popularity of gladiatorial shows in Italy is evidenced by the fact that there were 99 amphitheaters, of which 27 were studied by the archaeologists. All of them were built at the expense of city or at the expense of any individual, and sometimes the construction was partly financed by the emperor himself.

As Jacob Burckhardt considers, the Emperor Constantine the Great organized lavish celebrations and majestic circus games for inauguration of new city construction and giving it the name of Constantinople. Each year, a gilded statue of the emperor with Tyche, genius guard of the city, was carried through the circus in a torchlight procession. In the case of Constantine, the excessive pride and pompous performances were aimed at a deliberate political purpose. After 322 AD, wine, bread and oil was distributed on a permanent basis $^{37}$.

\section{Gladiatorial shows as a mass form of events. Statement of problem of ethical measurement of spectacles}

Under Octavian Augustus, various distributions for the Roman poor and free spectacles were arranged not from time to time, as during the Roman Republic, but constantly, becoming a guaranteed privilege for residents of Rome. On Octavian's part, it was not only generosity but also a kind of preventative measure aimed at preventing hunger riots and all kinds of protests.

${ }^{36}$ Wiedemann, Thomas E.J. (1992) Emperors and Gladiators. London; New York: Routledge, p. 180.

${ }^{37}$ Burckhardt Jacob (2003) Vek Konstantina Velikogo [The Age of Constantine the Great]. M.: Polygraph Center, pp. 86 (in Russian). 
In the document "Res gestae divi Augusti" (The Deeds of the Divine Augustus) (in Latin and Greek versions it is known from inscription in Ankara on Monumentum Ancyranum - O.G.), the Emperor Octavian Augustus details the statistics of mass spectacles and their costs. "I gave a gladiatorial show three times in my own name, and five times in the names of my sons or grandsons; at these shows about 10,000 fought. Twice I presented to the people in my own name an exhibition of athletes invited from all parts of the world, and a third time in the name of my grandson. I presented games in my own name four times, and in addition twenty-three times in the place of other magistrates. On behalf of the college of fifteen, as master of that college, with Marcus Agrippa as my colleague, I celebrated the Secular Games in the consulship of Gaius Furnius and Gaius Silanus. In my thirteenth consulship I was the first to celebrate the Games of Mars, which subsequently the consuls, in accordance with a decree of the senate and a law, have regularly celebrated in the succeeding years. Twenty-six times I provided for the people, in my own name or in the names of my sons or grandsons, hunting spectacles of African wild beasts in the circus or in the Forum or in the amphitheaters; in these exhibitions about 3500 animals were killed.I presented to the people an exhibition of a naval battle across the Tiber where the grove of the Caesars now is, having had the site excavated 1800 feet in length and 1200 feet in width. In this exhibition thirty beaked ships, triremes or biremes, and in addition a great number of smaller vessels engaged in combat. On board these fleets, exclusive of rowers, there were about 3,000 combatants (italic type is added by us - O.G. ${ }^{38}$. However, the Emperor Octavian Augustus was not the first to arrange public death battles.

${ }^{38}$ Shifman I.S. (1990) Deyaniya Bozhestvennogo Avgusta. Tsezar Avgust [The Deeds of the Divine Augustus. Caesar Augustus]. L.: Nauka, p. 184. (Iz istorii mirovoy kultury series [From the History of World Culture series]) (in Russian). 
It is known that the Etruscans turned the simple slaughter of prisoners of war sacrificed during burials into something else, namely, their fight not for life, but for death at the graves of ancestors and in the arena (probably the Romans adopted gladiatorial shows from Tarquinia) ${ }^{39}$. The Etruscan burial urns of the second half of the III century BC, depicting such fencing game, have survived. In these images, in two cases the Gauls confront their fellow men, and in the other case - the Gauls against the Thracians. Both of these combinations are well known to us by later gladiatorial shows of the Romans.

The term "munus" (plural - "munera") has been used constantly to refer to gladiatorial shows. If earlier they were carried out exclusively during burial of the deceased, that is, irregularly, then they were gradually transferred to December, when the Saturnalia was handled - festival in honor of the god Saturn, which was initially associated with human sacrifices. The dreaded gods of the underworld, as well as the gods of agriculture, were pacified with human blood.

The spectacular forms of events later, for example, became an important component of domestic politics in the ancient Rome. As Cicero states in the "Second Philippic against Mark Antony", the Emperor Gaius Julius Caesar "by gladiatorial shows, constructions, generous distributions and games attracted the inexperienced crowd to his side; his supporters tied with awards" ". In his speech "In defense of Publius Sestius" Cicero notes that "there has never been a greater crowd than at that gladiatorial shows, neither at any contio nor indeed

39 Hyofling G. (2010) Rimlyane, raby, gladiatory: Spartak u vorot Rima [Romans. Slaves. Gladiators. Spartacus at the gates of Rome]. M.: Center polygraph. Retrieved from: http://historylib.org/historybooks/KHelmut-KHefling_Rimlyane-raby--gladiatory-Spartak-u-vorot-Rima/2 (accessed on February 12, 2015) (in Russian).

${ }^{40}$ Cicero Marcus Tullius (1962) Vtoraya filippika protiv Marka Antoniya. Rechi $v$ dvukh tomakh [Second Philippic against Mark Antony. Speeches in two volumes]. Moscow: Publishing House of the Academy of Sciences of the USSR, Vol. 2, p. 319 (in Russian). 
any cornitium" " The ancient Greek historian Plutarch in "Comparative Biographies of Caesar" writes that "after the triumphs, Caesar gave his soldiers large gifts and entertained the people with banquets and spectacles ... furnishing spectacles of gladiatorial and naval combats in honor of his daughter Julia, long since dead" (italic type is added by us - O.G. $)^{42}$.

Not only obvious criminals, but sometimes innocent or wrongfully convicted people were sent to gladiatorial service. The gladiators were called infamous, as they were disenfranchised and had one of the worst ways of existence.

The oldest gladiator school in Capua belonged probably to Gaius Aurelius Scaurus, who, in 105 BC with the help of his teachers, taught the art of fencing to the legions of consul Rutilius. Three decades later, the famous school of Gnaeus Lentulus Batiatus had a bad record after about 70 gladiators led by Spartacus escaped from it in $73 \mathrm{BC}$.

The German-British historian Thomas Wiedemann explores comparative history of slavery and writes that the decree appears to have divided gladiatorial games into five separate categories, depending on the outlay: under 30,000 sesterces; 30 to 60,$000 ; 60$ to 100,$000 ; 100$ to 150,000 ; and 150 to 200,000 sesterces, the upper limit (and still half the equestrian census rating). Gladiators too were categorised by different price- bands: the lowest were gregarii, "ordinary" ones, costing between 1,000 and 2,000 sesterces; more expensive ones were assigned to three (possibly five) categories, the maximum being 15,000 sesterces $^{43}$.

${ }^{41}$ Cicero Marcus Tullius (1962) V zashchitu Publiya Sestiya. Rechi $v$ dvukh tomakh [In defence of Publius Sestius. Speeches in two volumes]. Moscow: Publishing House of the Academy of Sciences of the USSR, Vol. 2, p. 146 (in Russian).

42 Plutarch (1994) Sravnitelnye zhizneopisaniya $v$ dvukh tomakh. Tsezar. [Comparative life descriptions in two volumes. Caesar]. Editor S.S. Averintseva. M.: Nauka, Ed. 2. Vol. II, p. 55(in Russian).

3 Wiedemann, Thomas E.J. (1992) Emperors and Gladiators. London; New York: Routledge, p. 134. 
When analyzing the classification of gladiators, fighting couples, differences of their helmets and armor, role of gladiatorial shows in the mass interaction of the emperor with people of Roman Principate, the Swiss historian and museum expert Laurent Gorgerat in the study "Gladiator. Highly specialized fighter in the service of Roman virtues" identifies such types of gladiators as tracker, murmillo, provocator, hoplomachus, retiarius, secutor, arbelas ${ }^{44}$. Their goal has always been the will to fight at the highest technical level and thus to increase the attractiveness for the audience.

There were some differences among gladiators. Thus, murmillones received their name due to badge in the form of sea fish on a helmet. They were equipped with a Gallic shield, sword and spear. The retiarius, or net fighter, was another type of gladiator with apparently deep historical roots. Being dressed in a tunic shirt like fishermen, retiarii circled around their opponents, trying to throw a net on them to disable and kill with a dagger or trident that looked like the one used in tuna fishing. If the victim skillfully evaded, the retiarius quickly pulled the network to him with the help of a special cord and started "fishing" again. The Ukrainian researcher A. Obertynska wrote about the name of gladiatorial show "fishing" as settled in the history of mass games ${ }^{45}$. The main opponent of the retiarius next to the murmillo was the secutor (pursuer), the armor of which, as in the heavily armed samnite, consisted of a helmet with slot for eyes, sword and shield. The horse fighters, such as the andabata, were among them; their body was covered in Parthian chain mail and their faces were covered with deaf helmet with no slots for eyes. They were armed with long spears that they pointed at

${ }^{44}$ Gorgerat L. (September 2019) Der Gladiator. Ein hochspezialisierter Kämpfer im Dienste römischer Tugenden. Gladiator - Die wahre Geschichte. Eine Ausstellung des Antikenmuseum Basel und Sammlung Ludwig. Basel, Steudler Press AG, pp. 86-87.

${ }^{45}$ Obertynska A.P. (1992) Istorija masovykh svjat [History of Mass Holidays]. K.: NMK VO, p. 79 (in Ukrainian). 
each other at full speed. The essedarii fought in British chariots operated by the driver standing near ${ }^{46}$.

It is unknown when the female gladiator first appeared, as American researcher Anna McCullough writes in the article "Female Gladiators in Imperial Rome: Literary Context and Historical Fact". Their appearance probably coincided with the increasing popularity of games in general in the late Republican and Augustus era. B. Levick believes that women were first banned from entering the arena in $22 \mathrm{BC}$ by Augustus in the senatus consultum, which also banned the children and grandchildren of senators and horsemen from performing on stage and in the arena. Although Cassius Dio does not write specifically that women have been banned, he does mention both noble men and noble women who are banned from entering the arena in 23 and 22 BC. This ban of S.C. senate from being on stage and in the arena, if it did involve women, was repeated in 19 AD and was also applied to the daughters, granddaughters and greatgranddaughters of senators and horsemen. In $11 \mathrm{AD}$, the senate ban was applied to the free-born women under the age of twenty who could not enter the arena ${ }^{47}$.

Roman women as well as men found gladiatorial contests, and gladiators, attractive. Thomas Wiedemann draws attention to some much-quoted epigraphic evidence suggests that this attraction might be sexual: at Pompeii, the retiarius Crescens was known as 'the netter of girls by night' and 'the girls' darling'. Thracians were a favourite symbol of manliness because much of their body was left visible to the audience. Author considers that obviously constituted a potential danger to the Roman male's control over his womenfolk. Augustus

46 Hyofling G. (2010) Rimlyane, raby, gladiatory: Spartak u vorot Rima [Romans. Slaves. Gladiators. Spartacus at the gates of Rome]. M.: Center polygraph. Retrieved from: http://historylib.org/historybooks/KHelmut-KHefling_Rimlyane-raby--gladiatory-Spartak-u-vorot-Rima/2 (accessed on February 12, 2015) (in Russian).

${ }^{47}$ McCullough A. (Winter 2008) Female Gladiators in Imperial Rome: Literary Context and Historical Fact. Classical World. Johns Hopkins University Press. Vol. 101, No. 2, p. 198. 
restricted women, other than the six Vestal Virgins, to watching gladiators from the rearmost rows of seats ${ }^{48}$. However, Wiedemann's publication "Emperors and Gladiators" reflected his understanding of the essence of the Roman universe.

The Roman poet Marcus Valerius Martialis dedicated his epigram to Hermes, one of the most popular gladiators at the time:

Hermes, the martial pleasure of an age,

Hermes, well-learned in all arms,

Hermes, both gladiator and teacher,

Hermes, confusion and terror of his school,

Hermes, the only one whom Helius fears,

Hermes, the only one for whom Advolans fell,

Hermes, taught to conquer, not kill,

Hermes, himself his substitute,

Hermes, wealth of the scalpers,

Hermes, care and heartthrob of the slave-girls,

Hermes, warlike and arrogant with a spear,

Hermes, menacing with a sea trident ${ }^{49}$.

Hermes, his plumed helmet drooping, to be feared,

Hermes, glory of all kinds of war,

Hermes, alone is all and three in one $\mathrm{e}^{50}$.

During the secular games that took place at the circus in the presence of the Emperor Claudius (41-54 AD), as Cornelius Tacitus writes in his "Annals", "Publius Dolabella proposed that a spectacle of

48 Wiedemann, Thomas E.J. (1992) Emperors and Gladiators. London; New York: Routledge, p. 26.

${ }^{49}$ Martialis M.V. (1994) Epigrammy [Epigrams]. Translation by F.A. Petrovskyi. St. Petersburg: JSC "Komplekt", V. 24. Retrieved from: http://ancientrome.ru/ antlitr/t.htm?a=1312800455 (accessed on December 12, 2019) (in Russian).

${ }^{50}$ Martialis M.V. (1994) Epigrammy [Epigrams]. Translation by F.A. Petrovskyi. St. Petersburg: JSC "Komplekt", V, 31. Retrieved from: http://ancientrome.ru/ antlitr/t.htm?a=1312800455 (accessed on December 12, 2019) (in Russian). 
gladiators should be annually exhibited at the cost of those who obtained the quaestorship" ${ }^{\text {"51 }}$.

The Emperor Claudius himself was one of the fervent supporters of gladiatorial shows. Describing the emperor's preferences, Gaius Suetonius Tranquillus in his "The Twelve Caesars. Divine Claudius" writes that at gladiatorial shows, his own or others, he every time ordered to kill even those who fell by accident, especially the retiarii: he wanted to look in the face of the dying. "When a pair of gladiators had fallen by mutually inflicted wounds, he at once had some little knives made from both their swords for his use. He took such pleasure in the combats with wild beasts and of those who fought at noonday, that he would go down to the arena at daybreak and after dismissing the people for luncheon at midday" ${ }^{52}$. But one day he did well and appropriately: "he had granted the wooden sword to an essedarius, for whose discharge four sons begged, and the act was received with loud and general applause, he at once circulated a note, pointing out to the people how greatly they ought to desire children, since they saw that they brought favor and protection even to a gladiator" ${ }^{, 53}$.

The Roman writer Lucius Apuleius in his "The Metamorphoses or The Golden Ass" promises only to "please the reader's ear", that is, to entertain him; in fact, he fluently and vividly draws the various layers of modern society, culture, art, household activities and leisure; humor colors the whole narrative. The author tells how in

51 Tacitus Publius Cornelius (2001) Annaly. Malye proizvedeniya. Istoriya. [Annals. Small works. History]. Translation from Latin. M.: Publishing House AST LLC; Ladomir, XI, 22. (Klassicheskaya mysl series [Classical thought series]) (in Russian).

${ }_{52}$ Suetonius G.T. (1990) Zhizn dvenadtsati tsezarey [The Twelve Caesars]. Translation from Latin, foreword and afterword of M. Gasparov. M.: Khudozhestvennaya literatura, V. 34. Retrieved from: http://ancientrome.ru/antlitr/ t.htm? $\mathrm{a}=1354644432$ (accessed on January 17, 2015) (in Russian).

53 Suetonius G.T. (1990) Zhizn dvenadtsati tsezarey [The Twelve Caesars]. Translation from Latin, foreword and afterword of M. Gasparov. M.: Khudozhestvennaya literatura, V. 5. Retrieved from: http://ancientrome.ru/antlitr/ t.htm? $\mathrm{a}=1354644432$ (accessed on January 17, 2015) (in Russian). 
Plataea they heard a lot of talk about Demochares, who is going to organize the gladiatorial show. "... It would take more wit and eloquence than I am master of to do justice to each and every aspect of all his various preparations. There were gladiators renowned for their fighting prowess, hunters of proven speed and agility, and desperate criminals with nothing to lose who were being fattened up to fatten the beasts in their turn. There was an elaborate timber structure of several stories like a movable house, and brighdy decorated enclosures for the wild-beast show. The number and variety of the animals beggared description, for Demochares had gone to endless trouble to import exotic species to serve as tombs for the condemned. On top of the rest of the outfit for this splendid show he had pretty well used up everything he possessed in procuring a large number of huge bears, ${ }^{, 54}$.

However, in other people such violent fun and gladiatorial shows caused aversion and disgust, and in moral sense - condemnation. The Roman philosopher, poet and statesman of the I century AD, Lucius Annaeus Seneca, describes in his "Moral Letters to Lucilius" the favorite spectacle of many Romans: "Casu in meridianum spectaculum incidi, lusus exspectans et sales et aliquid laxamenti quo hominum oculi ab humano cruore acquiescant. By chance I attended a mid-day exhibition, expecting some fun, wit, and relaxation, - an exhibition at which men's eyes have respite from the slaughter of their fellow-men. But it was quite the reverse. The previous combats were the essence of compassion; but now all the trifling is put aside and it is pure murder. The men have no defensive armor. They are exposed to blows at all points, and no one ever strikes in vain.

Many persons prefer this program to the usual pairs and to the bouts "by request". Of course they do; there is no helmet or shield to deflect the weapon. What is the need of defensive armor, or of skill?

54 Apuleius Lucius. (1988) “Metamorfozy" $i$ drugie sochineniya ["Metamorphoses" and other works]; editor M.L. Gasparov. M.: Khudozhestvennaya literatura, IV, 13 (in Russian). 
All these mean delaying death. In the morning they throw men to the lions and the bears; at noon, they throw them to the spectators. The spectators demand that the slayer shall face the man who is to slay him in his turn; and they always reserve the latest conqueror for another butchering. The outcome of every fight is death, and the means are fire and sword. This sort of thing goes on while the arena is empty" ${ }^{, 55}$.

\section{Naumachia as a theatrical form of events of Rome. Spectacular politics of the emperors}

Naumachia (staging of naval battles in the artificial basin) was another spectacular form of events of the ancient Rome, reflecting the policy of "bread and circuses". As Plutarch notes in the "Comparative Biographies of Caesar", "...furnishing naval combats in honor of his daughter Julia" ${ }^{, 56} .4000$ rowers and 2000 gladiators took part in naumachia in the artificial basin on the Field of Mars. The next naumachia was arranged by the Emperor Augustus in the II BC on the occasion of inauguration of the Temple of Mars. The basin more than 500 meters long and about 400 meters wide was dug in the gardens on the right bank of the Tiber. It featured the famous battle between Greek and Persian ships, which took place in 480 BC near the Salamis in the Aegean Sea. More than three thousand people took part in this spectacle on dozens of large and small vessels.

The naumachia of the Emperor Claudius is described in "Annals" of the Roman historian Cornelius Tacitus. "Claudius equipped triremes, quadriremes, and nineteen thousand combatants: the lists he surrounded with rafts, so as to leave no unauthorized points of escape,

${ }^{55}$ Seneca Lucius Annaeus (1977) Nravstvennye pisma $k$ Lutsiliyu [Moral letters to Lucilius]. Translation, notes by S.A. Osherov, ed.-in-chief M.L. Gasparov. M.: Nauka, VII, 3-4. (Literaturnye pamyatniki series [Literary Monuments series]). Retrieved from: http://yakov.works/acts/01/2/seneca_001.htm (accessed on February 19, 2015) (in Russian).

56 Plutarch (1994) Sravnitelnye zhizneopisaniya $v$ dvukh tomakh. Tsezar. [Comparative life descriptions in two volumes. Caesar]. Editor S.S. Averintseva. M.: Nauka, Ed. 2. Vol. II, p. 55 (in Russian). 
but reserved space enough in the center to display the vigor of the rowing, the arts of the helmsmen, the impetus of the galleys, and the usual incidents of an engagement. ... The shores, the hills, the mountain-crests, formed a kind of theatre, soon filled by an untold multitude, attracted from the neighboring towns, and in part from the capital itself, by curiosity or by respect for the sovereign"57.

According to another Roman historian Gaius Suetonius Tranquillus, on the Field of Mars Claudius gave a military performance depicting the conquest and looting of the city and then conquest of British kings, and managed himself sitting in the cloak of the commander. "Indeed, he even staged a sea-battle on the Fucinc lake, when he was about to drain it. However, when those who were to fight called out: "Hail emperor! Those who are about to die salute you", he replied: "Or not". After that pronouncement, none of them was prepared to fight, arguing that he had thereby spared them",58.

The Roman poet Ovidius condemned the bloody fun of his contemporaries and in his "Grieving elegies" fervently called on the princeps (except for the other - Octavian Augustus), either jokingly or seriously, to ban the games, spectacle and circus.

Even if I'd confessed it, the games also sow

seeds of iniquity: order the theatres closed!

Many have often found an excuse for sin

when the hard earth's covered with Mars's sand!

Close the Circus! The Circus's freedom isn't safe:

here a girl sits close to an unknown man.

Why's any portico open, since certain girls

stroll there, to meet a lover in the place?

57 Tacitus Publius Cornelius (2001) Annaly. Malye proizvedeniya. Istoriya. [Annals. Small works. History]. Translation from Latin. M.: Publishing House AST LLC; Ladomir, XII, 56. (Klassicheskaya mysl series [Classical thought series]) (in Russian).

58 Suetonius G.T. (1990) Zhizn dvenadtsati tsezarey [The Twelve Caesars]. Translation from Latin, foreword and afterword of M. Gasparov. M.: Khudozhestvennaya literatura, V. 6. Retrieved from: http://ancientrome.ru/ antlitr/t.htm?a=1354644432 (accessed on January 17, 2015) (in Russian). 
... Or is this kind of writing safe on stage, where

it's allowed, and theatre grants license to the mime?

Well my poems have often been danced to, publicly ... ${ }^{59}$

A moral assessment of certain forms of events, wealth, hedonism can also be found in "Conversations on the Epistle to the Romans" of Saint John Chrysostom, court speaker, lawyer and Archbishop of Constantinople (347-406). As the saint writes “...I forbid you to dishonor yourself, wish that your pleasure was a real pleasure and not turned into punishment, torment, excessive drinking and great fun. Let the heathen know that Christians are best to have fun, but to decently have fun, because it is said, Rejoice the Lord with trembling (Psalms II, 11). How should we rejoice? Singing hymns, praying, singing psalms instead of shameful songs"60. Emphasizing the importance of moral virtues above all, Saint John Chrysostom draws the attention of the person to the fact that... "you build country houses, baths, galleries and many palaces without necessity and benefit, but you do not give Christ a small roof over his head, but decorate the upper parts of the house for crows and corshoons. What could be worse than such frivolity?"61.

59 Ovidius Publius Naso (1999) Ljubovni eleghiji. Mystectvo kokhannja. Skorbotni eleghiji [Love elegies. Art of love. Grieving elegies]. Translated by A. Sodomora. K.: Osnovy, II, 1 (in Ukrainian).

${ }^{60}$ Chrysostom John (1994) Izhe vo svyatykh ottsa nashego Ioanna Zlatoustogo arkhiepiskopa Konstantinopol'skogo izbrannye tvoreniya. Besedy na poslanie $k$ Rimlyanam [To the saints of our Father Saints John Chrysostom, Archbishop of Constantinople, chosen creations. Conversations on the Epistle to the Romans]. M., p. 789. (Reprinted edition: Tvoreniya svyatago ottsa nashego Ioanna Zlatoustago Arkhiepiskopa Konstantinopol'skago v russkom perevode [Creations of our holy Father Saints John Chrysostom, Archbishop of Constantinople, in Russian translation]. In 12 volumes. Vol. 9, Book 2. St. Petersburg: The Saint Petersburg Theological Academy, 1903) (in Russian).

${ }^{61}$ Chrysostom John (1994) Izhe vo svyatykh ottsa nashego Ioanna Zlatoustogo arkhiepiskopa Konstantinopol'skogo izbrannye tvoreniya. Besedy na poslanie $k$ Rimlyanam [To the saints of our Father Saints John Chrysostom, Archbishop of Constantinople, chosen creations. Conversations on the Epistle to the Romans]. M., p.677. (Reprinted edition: Tvoreniya svyatago ottsa nashego Ioanna Zlatoustago Arkhiepiskopa Konstantinopol'skago $\mathrm{v}$ russkom perevode [Creations of our holy Father Saints John Chrysostom, Archbishop of Constantinople, in Russian translation]. 
The leveling power of the imperial regime destroyed or falsified all patriarchal and ethnic and polis connections between people. The warmth of friendly feelings and real informal solidarity and friendship of ordinary people, family and community relations remained only in the collegiums ${ }^{62}$.

Thus, the spectacular events of the ancient Rome became an effective instrument of political domination. This sphere is truly a Roman art sphere, as it shows with utmost clarity and expressiveness, according to A.F. Losiev, how legal absolutism is synthesized in Rome with sensual diversity and internal sensual exaltation ${ }^{63}$. The Imperial Rome is a country of complete and true absolutism, kingdom of some state mysticism, before which a separate individual simply does not exist, he is only a screw in this universal machine.

\section{CONCLUSIONS}

The spectacular forms of events in the era of the ancient Rome were not just a form of everyday or social behavior, realization of religious and public festivals and mass spectacles, but largely reflected certain life positions, served as an important criterion for assessing the social role of person in the community, specified political power, reflected social and cultural transformations in society.

The transformations were traced in the daily life of the Roman. His main priorities are the clientele institute and its expansion, solemn sacrifices to a certain god, support of specially trained contestants, cult of power. Therefore, events as a spiritual category cannot be the subject of wishes and aspirations of the Roman.

In 12 volumes. Vol. 9, Book 2. St. Petersburg: The Saint Petersburg Theological Academy, 1903) (in Russian).

62 Petrova I.V. Formy dozvillja $v$ antychnosti: kuljturologhichnyj potencial [Forms of leisure in antiquity: cultural potential]. Retrieved from: http://www.culturalstudies.in.ua/knigi_8_45.php (accessed on January 25, 2015) (in Ukrainian).

${ }^{63}$ Losiev A. F. (2002) Ellinisticheski-rimskaya estetika I-II vekov [HellenisticRoman aesthetics of the I-II centuries]. Editors A.A. Takho-Godi, V.P. Troitsky. M.: Mysl, Vol. 5, Book 2. Retrieved from: http://psylib.org.ua/books/lose009/txt03.htm (accessed on November 2, 2019) (in Russian). 
The forms of events of free citizens of the ancient Rome can be divided into those that took place at home and those that took place in public place; rural and urban; active and passive; individual, group and mass; training, entertaining, educational; constructive and destructive; self-organized and socially organized. The cultural consciousness then decides according to its own faith and tastes mimesis or fantasy, nature or creativity, rules or freedom, rationality or emotions, objective or subjective.

In antiquity, there are two types of leisure activities: types and forms of leisure associated with religious worship, including mythology, traditional rites and rituals, mass actions, where, according to the classification of values of the ancient leisure, the leading values are cult and agony; types and forms of leisure associated with household activities, daily activities, individual characteristics of participants of leisure activities of the antiquity, where the values of orientation to communication and compensatory activity appear as primary ones.

The strengthening of supreme power in the state leads to the emergence of triumphs and religious and political festivals (first of all, festivals of the emperors - phenomenon of the Roman Empire). The Roman spectacles were a public demonstration of power, including military. Quite often they are carried out at the expense of the state, which significantly distinguishes them from the spectacles of sacred content, or are organized due to allowances of the officials who dream of relevant state positions. New leisure paradigm is being created that depends on many factors - social conditions, cultural resources, dominant ideologies and beliefs and more.

In the ancient Rome, labor and events differentiate becoming independent spheres of human life. They are closely intertwined with popular culture, folklore and folk festivals in the representatives of the broad circles. The leisure of wealthy and noble people takes new forms enriching with new content. The professions are born, the representatives of which are engaged in organization of entertainment of nobility in free time, as well as engaged in artistic crafts, art and 
philosophy. The specialists organizing public festivals and mass entertainment appear. The state plays an important role in organizing the honoring festivals, as it is interested in formation of appropriate stereotypes of thinking and behavior of citizens, and forming public opinion.

The ancient Rome left a significant cultural heritage. The expositions of British Museum, Gladiator Museum in Rome, Basel Museum of Antiquities and The Ludwig Collection and others have many artifacts of gladiatorial culture of the ancient Rome. For example, exhibition at the Gladiator Museum in Rome presents almost a thousand years of history of the Roman army and gladiators in one exposition, reconstruction of the most representative helmets and plate armor from the VII century BC to IV century $\mathrm{AD}^{64}$. The cultural and educational programs in museums allow fostering interest in the militaristic culture of the ancient Rome to different categories of visitors.

The reception of spectacular forms of events of the ancient Rome and their rethinking in the cultural dimension revealed the significant influence of values of the ancient spectacles on formation of spectacular culture in subsequent eras. The revival of the Olympic Games in 1896, renewal of the Pythian Games in 1999 (Delphic Games and Youth Delphic Movement), holding of Bosporus Agons International Festival of Ancient Art since 1999, holding of festivals of historical and cultural reconstructions "Kentavry" (Centauri) (Kyiv Oblast, Kopachiv village), "Ghenuezkyi sholom" (Genoese helmet) (Sudak), "Kamiana strila" (Stone arrow) (Kamianets-Podilsk) in modern Ukraine is the appeal to the cultural experience of Antiquity. However, creation of the concept of all-Ukrainian program of entertainment and leisure is not limited to the idea of reproduction of the ancient events and copying of ancient sights, the principle of

${ }^{64}$ Gladiator Museum Rome. Retrieved from: http://www.gladiatormuseum.com/ en/home/ (accessed on November 7, 2019). 
historical and cultural dialogue, study and revival of the best traditions is fundamental.

The modern event managers should be able to find director, conclude a contract, find art director, audio engineer, costume designer, stage workers, to determine the necessary equipment, schedule rehearsals, have regulatory foundations in the field of art and cultural practices, specific features of drafting business plan, budget, search for sponsors ${ }^{65}$.

The study of events of the Antiquity opens up new perspectives for study of spectacular culture in historical retrospect, for enrichment of the content and forms of modern leisure industry, optimization of modern methods of event management, improvement of quality of education of cultural scientists, as theoretical foundations of School of Cultural Studies of Kyiv National University of Culture and Arts.

The culturologists, teachers, students of departments for Cultural Studies and Event Management can use new information contained in this monograph section to develop and study courses "History and Theory of Culture", "History and Theory of Leisure", "History and Theory of Events".

\section{SUMMARY}

Purpose of the monograph section is introduction into the cultural discourse of analytically processed and summarized information on the genesis and evolution of forms of events in the ancient Rome, their functional features, specific features of mass events of Antiquity in the context of spectacular culture of Rome.

Methodological basis consisted of the methods of critical analysis of cultural, historical and literary sources, specific and historical analysis and interdisciplinary synthesis, induction and deduction. The problematic and chronological, system and

65 Novikova G.N. (2006) Tekhnologii art-menedzhmenta [Art management technologies]. M.: MGUKI, pp. 172-173 (in Russian). 
structural, comparative, descriptive methods and method of social and phenomenological analysis were applied from specific and scientific methods.

Scientific novelty. The monograph section analyzes the genesis and evolution of forms of events in the context of spectacular culture in the ancient Rome. Based on the ancient literary reflection, through the prism of works of culturologists, philosophers, historians, poets, writers of the ancient Rome Marcus Tullius Cicero, Gaius Suetonius Tranquillus, Josephus Flavius, Cornelius Tacitus, Plutarch, Lucius Annaeus Seneca, Pliny the Younger, Lucius Apuleius, Theodosius Macrobius, Publius Ovidius Naso, Marcus Valerius Martialis, Saint John Chrysostom, Dimitry of Rostov and others the author revealed the essence and content of games, festivals, theatrical performances, chariot racing, public executions, gladiatorial shows, naumachia as spectacular forms of events in the ancient Rome, statistics and specific features of spectacular events and instruments of ruling the Roman emperors. The author describes the moral aspects of events in the context of spectacular culture of antiquity.

Conclusions. The place of spectacular culture of Antiquity in the system of cultural knowledge and cultural tradition of their social universe is revealed. The transformations of spectacular events as a social and humanitarian experience of ancient society, political instrument of government in Rome are explored. The role of spectacles of Antiquity for modern cultural practices is established.

\section{REFERENCES}

1. Avanesova G. A. (2002) Kulturno-dosugovaya deyatelnost: teoriya i praktika organizatsii [Cultural and leisure activities: theory and practice of organization]. M.: Aspect Press, pp. 20-22 (in Russian).

2. Averintsev S. S. (1991) Antichnaya ritorika i sudby antichnogo ratsionalizma. Antichnayapoetika [Antique rhetoric and 
fate of antique rationalism. Antique poetics]. M.: Nauka, pp. 3-26 (in Russian).

3. Apuleius Lucius. (1988) "Metamorfozy" $i$ drugie sochineniya ["Metamorphoses" and other works]; editor M.L. Gasparov. M.: Khudozhestvennaya literatura, IV, 13 (in Russian).

4. Burckhardt Jacob (2003) Vek Konstantina Velikogo [The Age of Constantine the Great]. M.: Polygraph Center, pp. 86 (in Russian).

5. Genkina E.V. (1998) Tsennosti antichnogo dosuga kak sotsialno-kulturnaya sistema [Values of the ancient leisure as social and cultural system]: $\mathrm{PhD}$ in Pedagogy Thesis: 13.00.05. St. Petersburg, pp. 3-6 (in Russian).

6. Dmytrenko V. (2011) Oktavian Avghust. Narodzhennja Rymsjkoji imperiji [Octavian Augustus. Birth of the Roman Empire]. Lviv: Kalvariia, p. 253 (in Ukrainian).

7. Chrysostom John (1994) Izhe vo svyatykh ottsa nashego Ioanna Zlatoustogo arkhiepiskopa Konstantinopol'skogo izbrannye tvoreniya. Besedy na poslanie $k$ Rimlyanam [To the saints of our Father Saints John Chrysostom, Archbishop of Constantinople, chosen creations. Conversations on the Epistle to the Romans]. M., p. 789. (Reprinted edition: Tvoreniya svyatago ottsa nashego Ioanna Zlatoustago Arkhiepiskopa Konstantinopol'skago v russkom perevode [Creations of our holy Father Saints John Chrysostom, Archbishop of Constantinople, in Russian translation]. In 12 volumes. Vol. 9, Book 2. St. Petersburg: The Saint Petersburg Theological Academy, 1903) (in Russian).

8. Chrysostom John (1994) Izhe vo svyatykh ottsa nashego Ioanna Zlatoustogo arkhiepiskopa Konstantinopol'skogo izbrannye tvoreniya. Besedy na poslanie $k$ Rimlyanam [To the saints of our Father Saints John Chrysostom, Archbishop of Constantinople, chosen creations. Conversations on the Epistle to the Romans]. M., p. 677. (Reprinted edition: Tvoreniya svyatago ottsa nashego Ioanna Zlatoustago Arkhiepiskopa Konstantinopol'skago v russkom perevode [Creations of our holy Father Saints John Chrysostom, Archbishop of Constantinople, in Russian translation]. In 12 volumes. Vol. 9, 
Book 2. St. Petersburg: The Saint Petersburg Theological Academy, 1903) (in Russian).

9. Kliusko E. M. (2007) Dosug v kontekste sovremennykh vzglyadov na istoriografiyu [Leisure in the context of modern views on historiography]. Social and cultural activities: experience of historical research; collection of articles. Sc. ed. E.M. Kliusko, N.N. Yaroshenko. M.: MGUKI, pp. 33-34 (in Russian).

10. Cowell F. (2006) Drevniy Rim. Byt, religiya, kultura [Ancient Rome. Life, religion, culture] (electronic source). M.: Centrpoligraf. Retrieved from: http://historylib.org/historybooks/ Drevniy-Rim--Byt--religiya--kultura/ (accessed on September 15, 2019) (in Russian).

11. Kuzishchin V. I. (1973) Rimskoe rabovladelcheskoe pomeste [Roman Slave Estate] (electronic source). M: Moscow University. Retrieved from: http://historylib.org/historybooks/V-I-Kuzishchin_ Rimskoe-rabovlodelcheskoe-pomeste/7 (accessed on September 20, 2019) (in Russian).

12. Losiev A. F. (2002) Ellinisticheski-rimskaya estetika I II vekov [Hellenistic-Roman aesthetics of the I-II centuries]. Editors A.A. Takho-Godi, V.P. Troitsky. M.: Mysl, Vol. 5, Book 2. Retrieved from: http://psylib.org.ua/books/lose009/txt03.htm (accessed on November 2, 2019) (in Russian).

13. Macrobius Theodosius (2013) Saturnalii [Saturnalia]; translation by V.T. Zvirevich. M.: Krug, Vol. 4. Book 1, II, 5. (Humanities in research and translation) (in Russian).

14. Macrobius Theodosius (2013) Saturnalii [Saturnalia]; translation by V.T. Zvirevich. M.: Krug, Vol. 4. Book 1, VII, 25-26. (Humanities in research and translation) (in Russian).

15. Macrobius Theodosius (2013) Saturnalii [Saturnalia]; translation by V.T. Zvirevich. M.: Krug, Vol. 4. Book 1, VII, 34-35. (Humanities in research and translation) (in Russian).

16. Martialis M.V. (1968) Epighramy. Antychna literatura; khrestomatija [Epigrams. Ancient literature; chrestomathy]. Compiled by O.I. Biletskyi. K .: Rad. shkola, p. 550 (in Ukrainian). 
17. Martialis M.V. (1994) Epigrammy [Epigrams]. Translation by F.A. Petrovskyi. St. Petersburg: JSC "Komplekt", V. 24. Retrieved from: http://ancientrome.ru/antlitr/t.htm?a=1312800455 (accessed on December 12, 2019) (in Russian).

18. Martialis M.V. (1994) Epigrammy [Epigrams]. Translation by F.A. Petrovskyi. St. Petersburg: JSC "Komplekt", V, 31. Retrieved from: http://ancientrome.ru/antlitr/t.htm?a=1312800455 (accessed on December 12, 2019) (in Russian).

19. Mommsen Th. (1997) Iskusstvo i nauka. Istoriya Rima [Art and Science. History of Rome]. Editor-in-chief A.B. Yegorov, editor N.A. Nikitin. St. Petersburg: "Nauka", "Yuventa", p. 365 (in Russian).

20. Novikova G.N. (2006) Tekhnologii art-menedzhmenta [Art management technologies]. M.: MGUKI, pp. 172-173 (in Russian).

21. Obertynska A.P. (1992) Istorija masovykh svjat [History of Mass Holidays]. K.: NMK VO, p. 79 (in Ukrainian).

22. Ovidius Publius Naso (1999) Ljubovni eleghiji. Mystectvo kokhannja. Skorbotni eleghiji [Love elegies. Art of love. Grieving elegies]. Translated by A. Sodomora. K.: Osnovy, II, 1 (in Ukrainian).

23. Petrova I.V. (2012) Dozvillja u teoretychnykh refleksijakh: monoghrafija [Leisure in theoretical reflections: monograph]. K.: NAKKIM, p. 93 (in Ukrainian).

24. Petrova I.V. Formy dozvillja v antychnosti: kuljturologhichnyj potencial [Forms of leisure in antiquity: cultural potential]. Retrieved from: http://www.culturalstudies.in.ua/knigi_8_45.php (accessed on January 25, 2015) (in Ukrainian).

25. Sergeenko M.E., Dovatur A.I. (editors) (1982) Pisma Pliniya Mladshego: Knigi I-X [Pliny the Younger: Letters: Books I-X]. 2nd edition. Book X, 118 (in Russian).

26. Sergeenko M.E., Dovatur A.I. (editors) (1982) Pisma Pliniya Mladshego: Knigi I-X [Pliny the Younger: Letters: Books I-X]. $2^{\text {nd }}$ edition. Book IX, 32. Books I, 3; I, 9; IX, 7; IX, 36; IX, 40. Book. IX, 33. Books I, 15; IX, 17. Book IX, 20. Books IX, 6; IX, 23. Book IX, 39. Book X, 39. Book X, 118 (in Russian). 
27. Sergeenko M.E., Dovatur A.I. (editors) (1982) Pisma Pliniya Mladshego: Knigi I-X [Pliny the Younger: Letters: Books I-X]. $2^{\text {nd }}$ edition. Book IX, 23 (in Russian).

28. Sergeenko M.E., Dovatur A.I. (editors) (1982) Pisma Pliniya Mladshego: Knigi I-X [Pliny the Younger: Letters: Books I-X]. $2^{\text {nd }}$ edition. Book IX, 6 (in Russian).

29. Sergeenko M.E., Dovatur A.I. (editors) (1982) Pisma Pliniya Mladshego: Knigi I-X [Pliny the Younger: Letters: Books I-X]. $2^{\text {nd }}$ edition. Book X, 96 (in Russian).

30. Plutarch (1994) Sravnitelnye zhizneopisaniya $v$ dvukh tomakh. Tsezar. [Comparative life descriptions in two volumes. Caesar]. Editor S.S. Averintseva. M.: Nauka, Ed. 2. Vol. II, p. 61 (in Russian).

31. Plutarch (1994) Sravnitelnye zhizneopisaniya $v$ dvukh tomakh. Tsezar. [Comparative life descriptions in two volumes. Caesar]. Editor S.S. Averintseva. M.: Nauka, Ed. 2. Vol. II, p. 55 (in Russian).

32. Dimitry of Rostov (2006) Zhitiya svyatykh, izlozhennykh po rukovodstvu Chetikh-Miney v 12 tomakh [The Lives of Saints based on Cheti-Minei in 12 volumes]. K.: Publishing House of Kyiv Pechersk Lavra, Vol. 3, pp. 675-676 (in Russian).

33. Dimitry of Rostov (2006) Zhitiya svyatykh, izlozhennykh po rukovodstvu Chetikh-Miney v 12 tomakh [The Lives of Saints based on Cheti-Minei in 12 volumes]. K.: Publishing House of Kyiv Pechersk Lavra, Vol. 3, pp. 677-679 (in Russian).

34. Dimitry of Rostov (2006) Zhitiya svyatykh, izlozhennykh po rukovodstvu Chetikh-Miney v 12 tomakh [The Lives of Saints based on Cheti-Minei in 12 volumes]. K.: Publishing House of Kyiv Pechersk Lavra, Vol. 5, pp. 143-144 (in Russian).

35. Suetonius G.T. (1990) Zhizn dvenadtsati tsezarey [The Twelve Caesars]. Translation from Latin, foreword and afterword of M. Gasparov. M.: Khudozhestvennaya literatura, V. 21. Retrieved from: http://ancientrome.ru/antlitr/t.htm?a=1354644432 (accessed on January 17, 2015) (in Russian). 
36. Suetonius G.T. (1990) Zhizn dvenadtsati tsezarey [The Twelve Caesars]. Translation from Latin, foreword and afterword of M. Gasparov. M.: Khudozhestvennaya literatura, V. 34. Retrieved from: http://ancientrome.ru/antlitr/t.htm?a=1354644432 (accessed on January 17, 2015) (in Russian).

37. Suetonius G.T. (1990) Zhizn dvenadtsati tsezarey [The Twelve Caesars]. Translation from Latin, foreword and afterword of M. Gasparov. M.: Khudozhestvennaya literatura, V. 5. Retrieved from: http://ancientrome.ru/antlitr/t.htm?a=1354644432 (accessed on January 17, 2015) (in Russian).

38. Suetonius G.T. (1990) Zhizn dvenadtsati tsezarey [The Twelve Caesars]. Translation from Latin, foreword and afterword of M. Gasparov. M.: Khudozhestvennaya literatura, V. 6. Retrieved from: http://ancientrome.ru/antlitr/t.htm?a=1354644432 (accessed on January 17, 2015) (in Russian).

39. Seneca Lucius Annaeus (2011) Moraljni lysty do Lucylija [Moral letters to Lucilius]. Translated from Latin by A. Sodomora. K.: Apriori, pp. 132-133 (in Ukrainian).

40. Seneca Lucius Annaeus (1977) Nravstvennye pisma $k$ Lutsiliyu [Moral letters to Lucilius]. Translation, notes by S.A. Osherov, ed.-in-chief M.L. Gasparov. M.: Nauka, LXXVI, 4. (Literaturnye pamyatniki series [Literary Monuments series]). Retrieved from: http://yakov.works/acts/01/2/seneca_001.htm (accessed on February 19, 2015) (in Russian).

41. Seneca Lucius Annaeus (1977) Nravstvennye pisma $k$ Lutsiliyu [Moral letters to Lucilius]. Translation, notes by S.A. Osherov, ed.-in-chief M.L. Gasparov. M.: Nauka, VII, 34. (Literaturnye pamyatniki series [Literary Monuments series]). Retrieved from: http://yakov.works/acts/01/2/seneca_001.htm (accessed on February 19, 2015) (in Russian).

42. Tacitus Publius Cornelius (2001) Annaly. Malye proizvedeniya. Istoriya. [Annals. Small works. History]. Translation from Latin. M.: Publishing House AST LLC; Ladomir, XIII, 3. (Klassicheskaya mysl series [Classical thought series]) (in Russian). 
43. Tacitus Publius Cornelius (2001) Annaly. Malye proizvedeniya. Istoriya. [Annals. Small works. History]. Translation from Latin. M.: Publishing House AST LLC; Ladomir, XI, 10. (Klassicheskaya mysl series [Classical thought series]) (in Russian).

44. Tacitus Publius Cornelius (2001) Annaly. Malye proizvedeniya. Istoriya. [Annals. Small works. History]. Translation from Latin. M.: Publishing House AST LLC; Ladomir, XI, 22. (Klassicheskaya mysl series [Classical thought series]) (in Russian).

45. Tacitus Publius Cornelius (2001) Annaly. Malye proizvedeniya. Istoriya. [Annals. Small works. History]. Translation from Latin. M.: Publishing House AST LLC; Ladomir, XII, 56. (Klassicheskaya mysl series [Classical thought series]) (in Russian).

46. Utchenko S.L. (1972) Tsitseron i ego vremya [Cicero and his time]. M.: Mysl, p. 270 (in Russian).

47. Flavius Josephus (1994) Iudeyskie drevnosti [Antiquities of the Jews]. Translation from Greek by G.G. Geakel; foreword and notes by V.A. Fedosik, G.I. Dovgialo. Minsk, Vol. 2. XVII, 6, 5 (in Russian).

48. Hyofling G. (2010) Rimlyane, raby, gladiatory: Spartak $u$ vorot Rima [Romans. Slaves. Gladiators. Spartacus at the gates of Rome]. M.: Center polygraph. Retrieved from: http://historylib.org/ historybooks/KHelmut-KHefling_Rimlyane--raby--gladiatory-Spartaku-vorot-Rima/2 (accessed on February 12, 2015) (in Russian).

49. Cicero Marcus Tullius (1962) Rech ob otvetakh garuspikov. Rechi $v$ dvukh tomakh [On the Responses of the Haruspices. Speeches in two volumes]. Moscow: Publishing House of the Academy of Sciences of the USSR, Vol. 2, p. 189 (in Russian).

50. Cicero Marcus Tullius (1962) Rech protiv Gaya Verresa (Pervaya sessiya). Rechi $v$ dvukh tomakh [Speeches against Verres (First session). Speeches in two volumes]. Moscow: Publishing House of the Academy of Sciences of the USSR, Vol. 1, p. 53 (in Russian).

51. Cicero Marcus Tullius (1962) Vtoraya filippika protiv Marka Antoniya. Rechi $v$ dvukh tomakh [Second Philippic against Mark 
Antony. Speeches in two volumes]. Moscow: Publishing House of the Academy of Sciences of the USSR, Vol. 2, p. 319 (in Russian).

52. Cicero Marcus Tullius (1962) V zashchitu Publiya Sestiya. Rechi $v$ dvukh tomakh [In defence of Publius Sestius. Speeches in two volumes]. Moscow: Publishing House of the Academy of Sciences of the USSR, Vol. 2, p. 146 (in Russian).

53. Shifman I.S. (1990) Deyaniya Bozhestvennogo Avgusta. Tsezar Avgust [The Deeds of the Divine Augustus. Caesar Augustus]. L.: Nauka, p. 184. (Iz istorii mirovoy kultury series [From the History of World Culture series]) (in Russian).

54. Chumachenko B.M. (2003) Vstup do kuljturologhiji antychnosti [Introduction to the cultural studies of antiquity]. K.: KM Akademiia Publishing House, pp. 11-12 (in Ukrainian).

55. Chumachenko B.M. (2003) Vstup do kuljturologhiji antychnosti [Introduction to the cultural studies of antiquity]. K.: KM Akademiia Publishing House, pp. 24 (in Ukrainian).

56. Chumachenko B.M. (2003) Vstup do kuljturologhiji antychnosti [Introduction to the cultural studies of antiquity]. K.: KM Akademiia Publishing House, pp. 57 (in Ukrainian).

57. Beacham R.C. (2001) Spectacle Entertainments in early imperial Rome. Revista de Estudios Latinos (RELat), V. 1, p. 280.

58. Gladiator Museum Rome. Retrieved from: http:// www.gladiatormuseum.com/en/home/ (accessed on November 7, 2019).

59. Gorgerat L. (September 2019) Der Gladiator. Ein hochspezialisierter Kämpfer im Dienste römischer Tugenden. Gladiator - Die wahre Geschichte. Eine Ausstellung des Antikenmuseum Basel und Sammlung Ludwig. Basel, Steudler Press AG, pp. 86-87.

60. McCullough A. (Winter 2008) Female Gladiators in Imperial Rome: Literary Context and Historical Fact. Classical World. Johns Hopkins University Press. Vol. 101, No. 2, p. 198. 
61. McLean D., A.R. Hurd, N.B. Rogers (2008) Early history of recreation and leisure. Recreation and Leisure in Modern Society. Sudbury, Massachusetts: Jones and Bartlett, pp. 55-56.

62. Woolf, Gregory Duncan (2001) Inventing empire in ancient Rome. Empires Perspectives from archaeology and history. Editors S.E. Alcock; K.D. Mor; T.N. D'Altroy, K.D. Morrison, C.M. Sinopoli. Cambridge University Press, p. 320.

63. Wiedemann, Thomas E.J. (1992) Emperors and Gladiators. London; New York: Routledge, p. 180.

64. Wiedemann, Thomas E.J. (1992) Emperors and Gladiators. London; New York: Routledge, p. 134.

65. Wiedemann, Thomas E.J. (1992) Emperors and Gladiators. London; New York: Routledge, p. 26.

\section{Information about the author: Olena Goncharova,} Doctor of Cultural Studies, Professor, Professor at the Event Management and Leisure Industry Department, Kyiv National University of Culture and Arts 36, E. Konovalets str., Kyiv, 01601, Ukraine ORCID: http://orcid.org/0000-0002-8649-9361

Researcher ID: F-6473-2015 